$\begin{array}{llllllllll}P & R & Z & Y & C & Z & Y & N & K & \text { I }\end{array}$

\author{
Radosław Ptaszyński \\ https://orcid.org/0000-0001-7508-0496 \\ Instytut Historyczny Uniwersytet Szczeciński
}

\title{
Kampania antysemicka w środowisku lekarzy Szczecina 1967-1968. Przypadek Jerzego Gelbera
}

\begin{abstract}
Zarys treści: Artykuł jest analizą biografii wybitnego lekarza pediatry Jerzego Gelbera, ofiary antysemickiej czystki prowadzonej w Polsce od 1967 r. Losy Gelbera przedstawione są na tle antysemickiej kampanii prowadzonej na terenie Szczecina (podobnie jak w całym kraju) od 1967 r. Tekst jest także propozycją prowadzenia badań nad zjawiskiem pomarcowej emigracji z zastosowaniem metody biograficznej.

Abstract: The article is an analysis of the biography of the eminent paediatrician, Jerzy Gelber, who was a victim of an anti-Semitic purge carried out in Poland from 1967. Gelber's fate is presented against the background of the anti-Semitic campaign conducted in Szczecin (as well as the whole country) since 1967. The text is also a proposal to develop further research on March 68' emigration using the biographical method.
\end{abstract}

Słowa kluczowe: Marzec 1968, służba zdrowia, biografistyka, antysemityzm Keywords: March 1968, healthcare, biography, antisemitism

\section{Wstęp}

W dotychczasowej literaturze poświęconej emigracji Marca 1968 z terenu Pomorza Zachodniego w odniesieniu do środowiska lekarzy jako ofiar represji politycznej i kampanii antysemickiej wymienia się trzy osoby - Jerzego Gelbera, Juliana Szenkelbacha i Simę Wołyńską-Bochner ${ }^{1}$. Ich życiorysy są pobieżnie znane, jednak mówić tu można jedynie o krótkich biogramach, braku pełnej analizy i przede wszystkim wniknięcia w mechanizmy, które szanowanych lekarzy pozbawiły stanowisk i skłoniły do emigracji. Mimo że tematyka ta w skali ogólnopolskiej posiada

\footnotetext{
${ }^{1}$ E. Krasucki, Historia kręci drejdlem. Z dziejów (nie tylko) szczecińskich Żydów, Łódź 2018, s. 60, 245; J. Mieczkowski, Między emigracja a asymilacją. Szkice o szczecińskich Żydach w latach 19451997, Szczecin 1998, s. 11-12.
} 
obszerną literaturę, chciałbym zaproponować podejście bardziej pogłębione ${ }^{2}$. Praktycznie nic nie napisano dotychczas o dalszych losach emigrantów po 1968 r., pewnym uzupełnieniem są tu jedynie wywiady i reportaże $e^{3}$. Artykuł jest próbą uzupełnienia tych braków, ale także pierwszą propozycją prowadzenia znacznie szerszej niż dotychczas proponowana analiza, skupiającej się na istotnej grupie zawodowej z użyciem metody biograficznej. Łatwiej bowiem w oparciu o dotychczas znaną literaturę odtworzyć przebieg kampanii antysemickiej, nazywanej antysyjonistyczną, zarówno w skali kraju, jak i w województwie, trudniej zaś pokusić się o przełożenie jej na konkretne losy jednostek. Od razu należy też zasygnalizować, że w szczecińskim środowisku lekarzy i studentów medycyny ofiar kampanii antysemickiej było znacznie więcej niż trzy. Naturalnie nie sposób wyczerpać tej tematyki w jednym artykule, dlatego na tym etapie celem autora jest szczegółowe przedstawienie losów życia wybitnego medyka, ofiary czystki prowadzonej w Polsce od 1967 r., próba pokazania mechanizmów i ich wpływu na los jednostki. Ten istotny kontekst jest niezbędny do naszkicowania bardziej szczegółowego obrazu.

Spójrzmy na szczecińską prasę tego okresu. To, co jest w niej pisane, ma bardzo poważny wpływ na nastroje zarówno wśród Żydów, jak i ich otoczenia. Pracownicy mediów odpowiadają za tworzenie atmosfery nagonki. Bez nich, pasa transmisyjnego, słowa Gomułki, nawet wiece nie miałyby takiego zasięgu i wpływu. Bez nich nie powstałaby tak gęsta i nieprzyjemna atmosfera ${ }^{4}$. Trzeba też jednak pamiętać o tym, na co zwraca uwagę Sabina Baral: „program bez odbiorców pozostałby jedynie afiszem, tymczasem ten projekt znalazł wielu przekonanych i chętnych wykonawców. Łatwo im było się nad nami znęcać, bo byliśmy bezbronni. Ci zaś, którzy nie przykładali do tego ręki, starali się niczego nie zauważać"

Szczególne przykłady obsesji i gorliwości widzimy w publicystce Ireneusza Gwidona Kamińskiego z „Głosu Szczecińskiego”, organu KW PZPR. Dostrzegł on zaplanowaną strategię i taktykę „syjonizmu”, która polegać miała na skłonieniu

\footnotetext{
${ }^{2}$ Z klasycznej literatury przedmiotu wymienić trzeba naturalnie: M. Głowiński, Marcowe gadanie: komentarze do słów 1966-1971, Warszawa 1991; P. Osęka, Syjoniści, inspiratorzy, wichrzyciele. Obraz wroga w propagandzie Marca 1968, Warszawa 1999; D. Stola, Kampania antysyjonistyczna w Polsce 1967-1968, Warszawa 2000; J. Eisler, Polska rok 1968, Warszawa 2006; P. Osęka, Marzec '68, Kraków 2008; Oblicza marca, red. K. Rokicki, S. Stępień, Warszawa 2004; Tożsamość po pogromie. Świadectwa i interpretacje Marca '68, red. A. Molisak, P. Czapliński, Warszawa 2019.

${ }^{3}$ Por. T. Torańska, Jesteśmy. Rozstania '68, Warszawa 2008; J. Wiszniewicz, Życie przecięte. Opowieści pokolenia Marca, Wołowiec 2009; M. Grynberg, Księga wyjścia, Wołowiec 2018; K. Naszkowska, Ani tu, ani tam: Marzec '68: powroty, Warszawa 2018.

${ }^{4}$ Szerzej o publicystyce w tym okresie: W. Sęczyk, Marzec'68 w publicystyce PRL. Studium z dziejów propagandy, Wałbrzych 2009; A.B. Jarosz, Marzec w prasie, w: Marzec 1968. Trzydzieści lat później, red. M. Kula, P. Osęka, M. Zaremba, t. 1, Warszawa 1998, s. 99-125.

${ }^{5}$ S. Baral, Zapiski z wygnania, Kraków-Budapeszt 2015, s. 62.
} 
polskich Żydów do emigracji poprzez obietnice otrzymania 5 tys. dolarów na głowę oraz intratnej posady. Innym elementem tej „strategii” były „szeptana propaganda” i listy z pogróżkami oraz „skoordynowana akcja syjonistycznych środków masowego przekazu”. Celem było „oszczercze pomawianie narodu polskiego o antysemityzm, stworzenie psychozy emigracyjnej”. Elementem tego planu miał być również „obowiązek syjonistów działania na rzecz Izraela, czyli lojalności innej niż wobec kraju zamieszkania”. Wyobcowanie „społeczne i ideowe", oderwanie od klasy robotniczej zdaniem Kamińskiego doprowadziły zaś do powstania „syjonistycznego klanu”, który miał swoich teoretyków (profesorów z UW), przywódcę (Romana Zambrowskiego) i ideologię - syjonizm. Jego zdaniem ideologia ta nie różniła się niczym od ideologii hitleryzmu - uznania się za nadludzi. W istocie „klan” ten był agenturą wywiadów Izraela, RFN i USA jednocześnie. I wyrafinowane podsumowanie: „postawa dość charakterystyczna. Pogarda dla wszystkiego co polskie, wiara w wszechpotęgę syjonistycznej mafii. Dopiero dziś - lepiej późno niż wcale - odkrywamy mechanizm zaskakujących awansów, możnych protektorów, antyludowej, źródła bezkarności hochsztaplerów"6. W kolejnych zaś dniach ukazały się m.in. teksty: Syjonistyczne prowokacje w Nowym Jorku, Awanturnicza polityka osi Bonn-Tel Awiw. Wspólne agresywne cele, Kampania syjonizmu przeciwko Polsce, Macki na cały świat. Szin Bet - izraelskie szpiegostwo, Wrogowie szkaluja Polskę, Syjoniści opluwają Polskę i chyba najmocniejszy w tych smutnych czasach: Syjonistyczni plugawcy ${ }^{7}$.

Prasa informowała również o odezwach przyjmowanych na wiecach w zakładach pracy, w tym w szpitalach i na Akademii Medycznej. Przykładowo POP Wojewódzkiego Szpitala Zakaźnego przy ul. Arkońskiej: „Domagamy się kategorycznie przykładnego i konsekwentnego ukarania inspiratorów ostatnich zajść oraz wszystkich jawnych i ukrytych wrogów Polski Ludowej, zajmujących jeszcze odpowiedzialne stanowiska w naszym życiu państwowym i politycznym. Jesteśmy przeciwko tym, którzy strojąc się w togi obrońców polskiej kultury, są jej zaciętymi wrogami”. Poinformowano, że na zebraniu tym wstąpiło w szeregi PZPR ośmiu pracowników szpitala, w tym lekarze Waldemar Dobrzyński i Jolanta Paprocka. Na PAM do partii wstąpiło wówczas 11 osób.

W początku kwietnia nowy impuls dało wystąpienie Antoniego Walaszka na wiecu w Stoczni Szczecińskiej im. Adolfa Warskiego. I sekretarz KW zapowiedział wówczas, że proces oczyszczania partii z syjonistów i rewizjonistów zostanie doprowadzony do końca: „Będziemy oczyszczali partię i aparat władzy z reakcjonistów, syjonistów i wszystkich innych ludzi, którzy postępowaniem swoim dają dowody, że nie są z partią, nie są z narodem polskim, nie są za socjalizmem.

\footnotetext{
${ }^{6}$ I.G. Kamiński, Taktyka i praktyka, „Głos Szczeciński” 17 IV 1968 r.

${ }^{7}$ B. Janiszewski, Syjonistyczni plugawcy, „Głos Szczeciński” 2 IV 1968 r.
} 
Jeżeli tacy ludzie zawinili wobec Polski, muszą zapłacić za to, zanim będą mogli opuścić kraj, który nie uważają za swoją ojczyznę"8.

Ze względu na braki w materiale źródłowym bardzo trudno dziś odtworzyć nastroje, jakie panowały w Pomorskiej Akademii Medycznej lub w poszczególnych klinikach w interesującym nas okresie. $Z$ powodu braku akt komitetu uczelnianego i organizacji partyjnych część mechanizmów nagonki nie jest jasna. To jedno z kluczowych pytań: czy decyzje podejmowała Służba Bezpieczeństwa, władze uczelni, bezpośredni przełożeni czy może organizacja partyjna? Wydaje się, że ta ostania miała stosunkowo dużo do powiedzenia wobec członków partii, ale to również bezpośrednie naciski $\mathrm{SB}$, także celowe tworzenie nieprzychylnej, wrogiej atmosfery. Wydaje się, że bardzo dużo działo się w sposób zakulisowy, bez pozostawienia śladu $\mathrm{w}$ dokumentach. Jeszcze inaczej wyglądało to $\mathrm{w}$ przypadku wojska, gdzie rozkazem odwoływano ze stanowiska. W przypadku Szczecina dotyczyło to Szymona Remigolskiego, ordynatora Oddziału Chirurgii w 109. Szpitalu Wojskowym ${ }^{9}$. Ważnym kontekstem są przeżycia przedwojenne, czasu Zagłady, a również powojenne - osobiste doświadczenie antysemityzmu, czasem bezpośredniego zagrożenia życia.

Ślady atmosfery panującej w środowisku lekarskim znajdujemy w codziennie przesyłanych meldunkach szefa lokalnej SB. Materiały te wydają się mało reprezentatywne, bazują bowiem na jednostkowych donosach, a te bardzo często na plotkach. Warto jednak sprawdzić i to źródło. W końcu marca $1968 \mathrm{r}$. raportowano: „studenci i część kadry naukowej Pomorskiej Akademii Medycznej oczekuje, kiedy tutejsze władze przystąpią do oczyszczania tej uczelni z syjonistów, gdyż jest ona w dużym stopniu opanowana przez zgraną klikę żydowską. $\mathrm{Z}$ dużym zadowoleniem przyjęto wykluczenie $\mathrm{z}$ partii sztandarowego syjonisty Szenkelbacha i oczekują w związku z tym na konkretne decyzje administracyjne. Natomiast studenci pochodzenia żydowskiego w dyskusjach usiłują przekonać swoich rozmówców, że w Polsce panuje antysemityzm, czego dowodem jest zdejmowanie ich ze stanowiska bez podania przyczyn i dowodów. Twierdzą przy tym, że «to nalatywanie na Żydów może Polakom wyjść bokiem»"10. Inny dokument tej samej proweniencji: „W Pomorskiej Akademii Medycznej rozeszła się pogłoska, że ponownej weryfikacji zostaną poddane kandydatury na praktyki zagraniczne, a szczególnie ma to dotyczyć studentów Żydów. Z tego powodu wszyscy studenci żydowscy są niesłychanie podnieceni i oburzeni. (fragment skreślony: również niektórzy polscy studenci wyrażają opinie, że nie byłoby słuszne, aby tylko z powodu obcej narodowości nie przyznawano praktyk zagranicznych)"11.

\footnotetext{
${ }^{8}$ Siła partii w jej masach, „Głos Szczeciński” 8 IV 1968 r.

9 Szerzej: R. Ptaszyński, Zbędny, „Newsweek Historia” 2020, nr 4, s. 72-75.

${ }^{10}$ Archiwum Instytutu Pamięci Narodowej (dalej: AIPN) Oddział w Szczecinie (dalej: Sz), sygn. 0011/10005, t. 2, Szyfrogram nr 259 z 29 III 1968 r., k. 131.

${ }^{11}$ Ibidem, Szyfrogram 1 IV 1968 r., k. 122.
} 
W kontekście działań partii na Pomorskiej Akademii Medycznej, w tym jej udziału w prowadzeniu czystki, uwagę zwraca inny raport: „w uczelni tej jest stosunkowo dużo osób pracowników naukowych narodowości żydowskiej. Dyskusja koncentruje się głównie wokół osoby sekretarza KU PZPR prof. Eugeniusza Łempickiego ${ }^{12}$, który jest pochodzenia żydowskiego. $\mathrm{Z}$ wypowiedzi tych wynika, że wielu członków partii jest za tym, aby nie pełnił on tej funkcji nadal, z uwagi na to, że niezbyt zdecydowanie występował przeciwko niektórym pracownikom naukowym pochodzenia żydowskiego, którzy wyrażali poparcie dla Izraela. (ostatnie zdanie zostało skreślone)"13. Otóż Łempicki nie był pochodzenia żydowskiego; to że taka nieprawdziwa informacja pada, pokazuje pewien rozpowszechniony wówczas w całym kraju mechanizm - rewolucja może zacząć zjadać własne dzieci, każdy może być „podejrzany”. Rozpowszechniają się plotki o tym, kto jest lub może być Żydem. Kwitną także powszechnie „analizy” antropologiczne, baczniejsze przyglądanie się kolorowi włosów, oczu, kształtu nosa, brzmienia nazwiska rozmówcy.

W środowisku studentów medycyny pochodzenia żydowskiego, których zresztą licząc wszystkie lata $\mathrm{z}$ całą pewnością nie było więcej niż 20, SB w tym czasie obserwowała „ruchliwość”. Trudno powiedzieć dziś, co dokładnie miałoby oznaczać to określenie. Z kontekstu możemy domyślać się, że chodziło po prostu o spotkania w prywatnych mieszkaniach ${ }^{14}$.

Analizując codzienne szyfrowane meldunki wysyłane przez szefa szczecińskiej SB płk. Romualda Głowackiego do Ministerstwa Spraw Wewnętrznych trudno pozbyć się wrażenia, że SB zajmuje się nie tylko informacją, lecz także kreacją nastrojów osób, do których raporty trafiały. Dotyczy to przede wszystkim trudno weryfikowalnych postulatów wygłaszanych zdaniem piszącego powszechnie, a odnoszących się do przeprowadzenia głębokiej czystki. Przykładowo: „zdecydowanie przeważa opinia zarówno w środowiskach robotników, jak i inteligencji oraz pracowników umysłowych, że w referacie tow. Gomułki nie rozprawiono się dostatecznie z syjonizmem oraz nie udzielono odpowiedzi na liczne wnioski domagające się oczyszczenia partii i aparatu państwowego z syjonistów”15.

\footnotetext{
12 Eugeniusz Łempicki (1905-1989) - absolwent Wydziału Farmaceutycznego Uniwersytetu Warszawskiego; 1939 dr farmacji; żołnierz kampanii wrześniowej 1939 r. (Szpital Okręgowy nr 6. Warszawa) od 1950 r. w PAM; 1955-1960 i 1969-1972 prodziekan Wydziału Lekarskiego; 1961-1976 kierownik Zakładu/Katedry Chemii Fizjologicznej; sekretarz Komitetu Uczelnianego, Oddziałowej Organizacji Partyjnej przy szpitalu na Pomorzanach i członek Komitetu Wojewódzkiego PZPR; członek Ochotniczej Rezerwy Milicji Obywatelskiej; od października 1976 r. na emeryturze; brat Mariana Łempickiego - przewodniczącego Prezydium Wojewódzkiej Rady Narodowej w Szczecinie. 70 lat Pomorskiego Uniwersytetu Medycznego w Szczecinie, red. I. Kojder, Szczecin 2018, s. 119.

${ }^{13}$ AIPN, Sz, sygn. 0011/10005, t. 2, Szyfrogram 464 z 29 IV 1968 r., k. 41.

${ }^{14}$ Ibidem, Szyfrogram z 26 IV 1968 r., k. 44.

${ }^{15}$ Ibidem, Szyfrogram nr 170 z 20 III 1968, k. 160.
} 
Według danych SB do końca 1969 r. z terenu województwa dokumenty wyjazdowe złożyły 762 osoby, a 63 osoby pobrały promesy. Z tego wyjechały 573 osoby, w tym jak obliczano 103 rzemieślników, 82 pracowników umysłowych, 55 studentów, 22 lekarzy. Według danych tej instytucji w Szczecinie pozostało około 3 tys. osób narodowości żydowskiej, często w rodzinach mieszanych ${ }^{16}$.

Inaczej niż w przypadku propagandy medialnej, Głowacki nie unika słowa „Żyd”, które w zasadzie występuje u niego równie często jak „syjonista”; co więcej w jego raportach pojawia się też szczególnie traumatycznie brzmiąca kalka - „kwestia żydowska”.

Jak wyglądało to z perspektywy młodych Żydów? W zasadzie wszyscy absolwenci czołowych szczecińskich liceów mówią o braku jakichkolwiek przejawów antysemityzmu ze strony rówieśników w szkole i w czasie studiów medycznych. Na ulicy bywało jednak inaczej; tam gdzie wiedziano, że mieszkają Żydzi, tam gdzie wygląd był „nieodpowiedni” pojawiała się przemoc i atak ze strony polskich sąsiadów. Wspomina Leon Szyfer: „Niebuszewo miało znaczną ludność żydowską, ale my nadal byliśmy mniejszością. Nazywanie «żydek», "parch», «parszywy Żyd» było czymś bardzo normalnym. Bardzo często napotykaliśmy na fizyczne nękanie, zwłaszcza gdy staliśmy samotnie przed grupą polskich chłopców”17. O atakach wspomina także Luba Tarczyńska: „W naszym Klubie ciągle wybijano szyby. Czy dlatego, że prawie przez ścianę sąsiadował z kościołem? W każdym razie dla mnie to było bardzo nieprzyjemne i się dziwiłam, że większość ludzi z Klubu przyjmowała to z zupełnym spokojem [...]. Taką jakąś pewność w sobie mieli - że my jesteśmy Żydzi, że jesteśmy "ponad to» - i chyba to była nie tylko pewność, ale i zarozumiałość jakaś, powiedziałabym"18.

Mietek Klajman wspominał po prostu uczucie zagrożenia: ,jak gazety zaczęły pisać o Dajczgewandzie, którego znałem przecież dobrze z kolonii żydowskich, i kto popiera syjonistów, a kto jest syjonistą, i się zaczęła cała ta gra między Moczarem i Gomułką, to nawet czułem strach! I przemówienie Gomułki dziewiętnastego marca w Sali Kongresowej, że Żydzi nielojalni wobec Polski powinni wyjechać, i publikowanie takich małych książeczek, że Żydzi są zagrożeniem dla Polski, i to że czasem do niektórych żydowskich rodzin w Szczecinie stukano do drzwi w nocy i wołano żeby wyjeżdżali! To chyba było przez milicję robione specjalnie , żeby ludzie się wynieśli i zostawili im swoje mieszkania - więc we mnie był strach. [...] A jeszcze dużo w Marcu w ogóle dopiero dowiadywało się, że są Żydami! Kiedy poszedłem odebrać dokument podróży, to tam spotkałem ludzi, co mi

\footnotetext{
${ }^{16}$ AIPN Sz, 0012/9, Sprawozdanie z pracy Służby Bezpieczeństwa województwa szczecińskiego w roku 1969 z 29 I 1970 r., k. 3.

${ }^{17}$ Relacja Leona Szyfera na zamkniętej grupie Facebook „Szczecin in Israel and Diaspora”.

${ }^{18}$ J. Wiszniewicz, op. cit., s. 455
} 
do głowy nie przyszło nawet!”19. Powrócił zatem demon ustaw norymberskich - „aryjskość” lub jej brak. To powodowało poczucie absurdu, niezrozumienia sytuacji, ale też nutkę żalu.

Jednak nie wszyscy wyemigrowali. Najbardziej znaną osobą ze świata medycyny, która została w Szczecinie poza Eisnerem był Szymon Remigolski, ale zostali również między innymi Pegi Otrębska ${ }^{20}$, Margarita Goldin ${ }^{21}$, Salomon Samler (twórca i prezes spółdzielni Medicus) ${ }^{22}$, Karol Stański² ${ }^{23}$, Henryk Płoń$\mathrm{ski}^{24}$. W kontekście opisywanych wydarzeń specyficzne są losy Marka Eisnera - wybitnego profesora, ikony szczecińskiej medycyny ${ }^{25}$. Eisner nigdy nie krył

${ }^{19}$ Ibidem, s. 461-463. Koresponduje to z relacją Władysława Bieńkowskiego: „Instytucje otrzymywały gotowe spisy zatrudnionych u nich Żydów, listy sporządzone z dużą wnikliwością - zdarzało się, że zainteresowani dopiero z tego źródła dowiadywali się, że są Żydami”, por. W. Bieńkowski, Motory i hamulce socjalizmu, Paryż 1969, s. 49.

${ }^{20}$ Pegi Otrębska z d. Kliger (1946-2007) - ur. w m. Szymkent w Kazachstanie, lekarz ginekolog; adiunkt w Klinice Patologii Ciąży i Porodu PAM; matka Iza Sztrom (pracownia bieliźniarska), ojciec Marian; AIPN, Sz, 468/21516, Akta paszportowe.

${ }^{21}$ Margarita Goldin (ur. 1942) urodzona w m. Akuticha w Kraju Ałtajskim, absolwentka PAM w Szczecinie (1967) od 1975 r. lekarz w Wojewódzkim Szpitalu Zespolonym w Szczecinie; ojciec Michał (Chaim) do 1954 naczelnik Wojewódzkiego Oddziału Konsumów WUBP Szczecin; matka Ewa Segał księgowa m.in. w MO, PAM i „Orbisie”. AIPN, Sz, 468/19406, Akta paszportowe.

${ }^{22}$ Salomon Samler (1909-1990) - ur. w Nadwornej koło Stanisławowa, tam do 1941 r. następnie w m. Zyrjanowsk w Kazachstanie protetyk i dentysta; rodzice i rodzeństwo zginęli w czasie wojny; przed wojną technik dentystyczny praktykant; w Szczecinie od 1946 r.; w 1946-1948 technik dentysta w Szpitalu WUBP w Szczecinie; założyciel i prezes spółdzielni Medicus. AIPN, Sz 0019/3451, Akta osobowe funkcjonariusza.

${ }^{23}$ Karol Stański (1898-1987) - lekarz pediatra; dr n. med. ur. w Tarnopolu; studiował w Wilnie i we Lwowie (dyplom 1925); specjalizacja w Wiedniu; 1928-1942 lekarz w m. Czerniatyń; od 1939 r. dyrektor poliklinik w Horodence; od 1941 r. lekarz szpitala zakaźnego; od 1942 r. ukrywał się; aresztowany i torturowany; po ucieczce w partyzantce w okolicy Horodenki; W VIII 1944 r. został zmobilizowany do Wojska Polskiego i przydzielony początkowo do tzw. Punktu Ewakuacyjnego przy 2 Armii, a następnie do 20. Szpitala Polowego; 1945-1946 szef oddziału Szpitala Garnizonowego Chełmnie, następnie szefem oddziału w Sanatorium Wojskowym Ciechocinek; od I 1947 r. lekarz pediatra Szpitala Garnizonowego w Szczecinie; od 1950 r. lekarz pediatra pierwszego w Szczecinie żłobka tygodniowego; 1949-1952 szef Wojskowej Komisji Lekarskiej; od 1952 pediatra Oddziału Ginekologiczno-Położniczego z Pododdziałem Dziecięcym 109. Szpitala Wojskowego; równolegle od 1954 r. pediatra w Przychodni Dziecięcej nr 2; w czasie nagonki antysemickiej był już poza wojskiem, przyjmując jedynie prywatnie; dwukrotnie żonaty, jego córka wyemigrowała do Izraela. Wojskowe Biuro Historyczne (dalej: WBH), Teczka Akt Personalnych, sygn. 830/62/71.

${ }^{24}$ Henryk Płoński (1926-2017) - ur. w Łodzi; lekarz, więzień obozów w Auschwitz i Stutthofie.

${ }^{25}$ Marek Eisner (1907-1994) - lekarz endokrynolog i internista; profesor PAM; syn Jakuba i Reginy Citron; 1932 r. absolwent Uniwersytetu w Wiedniu; 1934-1937 wolontariusz Szpitala Św. Ducha w Warszawie; 1937-1943 lekarz w Borszczowie; 1943-1944 lekarz w getcie w Borszczowie i ukrywał się w okolicy miasta (określił się później „szczęśliwcem, któremu ukrycie zaproponowali Polacy i Ukraińcy"); 1944-1946 lekarz szpitala i Domu Dziecka w Borszczowie; od 1946 r. w Szczecinie; 1946-1953 lekarz Ubezpieczalni Społecznej; 1947-1948 lekarz szpitala PCK; 
swojego pochodzenia, jednak nie dotknęły go represje antysemickiej nagonki 1968 r. Według wspomnienia jego współpracowniczki Idalii Gołębiewskiej „profesor został wezwany do rektoratu, kazano mu złożyć wypowiedzenie. Przyszedł później do mnie do laboratorium i opowiadał ze łzami w oczach. Mówił, co im odpowiedział, że skoro oni go przyjęli, niech oni go zwolnią i podadzą przyczynę. Mówił, że nie zostawi swoich pacjentów i kliniki. Przetrwał"26. Inne powody, które wydają się również logicznie uzasadnione głoszą, że w komitecie partii obawiano się o stratę znakomitego lekarza, z którego wiedzy chętnie korzystano, a ponadto zawsze można było pokazać, że represje nie dotyczą wszystkich Żydów, bo tak znana postać jak Eisner nie tylko nie emigruje, ale i nie traci stanowiska.

Łącznie mówić można o około 30 szczecińskich lekarzach i studentach medycyny, którym Marzec przeciął życie. Warto przyjrzeć się szczegółowo losom niektórych emigrantów; jednym ze szczególnych jest biografia Jerzego Gelbera.

\section{Ze Lwowa do Szczecina}

Urodził się w Tarnopolu 10 stycznia $1914 \mathrm{r}$. w rodzinie inżyniera kolejowego Józefa i Doroty Halpern, będącej na utrzymaniu męża. Do 1931 r. mieszkał w Tarnopolu z rodzicami. Szkołę podstawową i gimnazjum ukończył jednak we Lwowie. Tam też rozpoczął studia na Wydziale Lekarskim Uniwersytetu Jana Kazimierza. W czerwcu 1937 r. otrzymał dyplom, a już we wrześniu tego roku został powołany do wojska. Służbę wojskową odbywał w Centrum Wyszkolenia Sanitarnego w Warszawie, a następnie jako plutonowy podchorąży lekarz w Przemyślu. Po zwolnieniu z wojska od 1938 r. pracował jako lekarz w Szpitalu Powszechnym we Lwowie i Szpitalu Ubezpieczalni Społecznej. 5 września 1939 r. został zmobilizowany jako lekarz batalionu w stopniu podporucznika i brał udział w kampanii wrześniowej do 22 września, służąc na oddziale chirurgicznym 604. szpitala wojennego we Lwowie ${ }^{27}$.

W lutym 1940 r. został zatrudniony w Katedrze Biochemii we Lwowie, zaś od września 1941 r. do września roku następnego był lekarzem I Polikliniki w tym

od 1948 r. w Klinice Chorób Wewnętrznych PAM; kierownik III Kliniki Chorób Wewnętrznych szpitala przy ul. Arkońskiej; od 1956 r. zast. kierownika Kliniki Chorób Zakaźnych PAM; organizator i kierownik Kliniki Endokrynologii PAM; pracował także po przejściu na emeryturę w 1977 r.; opublikował ok. 80 prac naukowych; odznaczony m.in. Krzyżem Kawalerskim i Oficerskim Orderu Odrodzenia Polski; słynny z tego, że wolny czas spędzał studiując zagraniczną literaturę fachową w bibliotece PAM, a niemal do ostatnich dni życia był gotów do konsultacji całą dobę we wszystkich oddziałach szpitala. Szerzej: Marek Eisner, red. I. Kojder, Szczecin 2014.

${ }^{26}$ M. Adamowska, Prof. Marek Eisner. Wielki lekarz małych ludzi [Lekarze czy bogowie], „Gazeta Wyborcza Szczecin" 20 II 2015.

${ }^{27}$ Archiwum Pomorskiego Uniwersytetu Medycznego (dalej: APUM), Akta personalne Jerzego Gelbera. 
samym mieście. Został we Lwowie, chcąc zaopiekować się rodzicami, zaś jego brat Ludwik po udziale kampanii wrześniowej przedostał się z wojskiem na Zachód, gdzie służył m.in. jako lekarz-spadochroniarz I Samodzielnej Brygady Spadochronowej gen. Stanisława Sosabowskiego ${ }^{28}$.

W 1940 r. zmarł ich ojciec. Po wejściu Niemców do Lwowa mieszkanie Gelberów zostało zarekwirowane. W kamienicy, do której ich przesiedlono, Jerzy poznał swoją przyszłą żonę, Annę Kułaj. To ona i jej rodzina (żołnierzy AK i konwertytów na katolicyzm) wyciągnęła Jerzego i jego matkę z getta oraz zorganizowała fałszywe dokumenty na nazwisko Paweł Ostrówka. Gelberowie byli ukrywani w miejscowościach Mielnica, Kniaże, Raćmirowa i Zawada koło Nowego Sącza. Jerzy dorywczo pracował też jako buchalter w majątkach należących do pomagających mu Polaków. W Kniażach dzięki szczególnej pomocy miejscowego księdza Tadeusza Wacha ${ }^{29}$ pod przybranym nazwiskiem wziął ślub katolicki z Anną, co pozwoliło mu także na uzyskanie poświadczonego przez Kościół dokumentu stwierdzającego, że jest katolikiem. Oboje z matką przeżyli wojnę. Czas Zagłady pozostawił jednak trwałe piętno na ich życiu. Był też tematem, o którym nie rozmawiano w rodzinie nigdy.

W lutym 1945 r. Gelber ochotniczo zgłosił się do Wojska Polskiego, gdzie służył jako lekarz, najpierw w Rzeszowie (w komendzie uzupełnień), następnie jako ordynator Oddziału Wewnętrznego Szpitala Okręgowego nr 5 w Krakowie. Jednocześnie (od października 1946 r.) pracował jako lekarz ubezpieczalni społecznej. W tym czasie otrzymał telefon od gospodyni zatrzymanego przez Urząd Bezpieczeństwa ks. Wacha, która prosiła o pomoc zatrzymanemu i torturowanemu księdzu. Gelber w mundurze Wojska Polskiego zdecydował się interweniować. Księdza wypuszczono ${ }^{30}$.

Mieszkając w Krakowie, przypadkowo na ulicy spotkał znanego mu wcześniej ze Lwowa prof. Artura Chwalibogowskiego ${ }^{31}$, który poinformował go, że będzie brał udział w organizacji Akademii Lekarskiej w Szczecinie i zaproponował wspólny wyjazd. Odszedł z wojska na własną prośbę w stopniu kapitana,

${ }^{28}$ Szerzej: A. Rutkiewicz, Działania desantowe służby zdrowia 1 Samodzielnej Brygady Spadochronowej w operacji „Market Garden”, „Przegląd Historyczno-Wojskowy” 2017, nr 2, s. 119-146. Ludwik Gelber zmarł w $1954 \mathrm{r}$.

29 Tadeusz Wach (1892-1965) wyświęcony w 1933 r., przed wojną w archidiecezji lwowskiej; XI 1945-I 1946 wikary substytut parafii w Wójcicach; 1946-1964 proboszcz parafii w Trzeboszowicach. A. Hanich, Dekanaty i parafie administracji apostolskiej Śląska Opolskiego w latach 1945-1946, Opole 2009, s. 306.

${ }^{30}$ Relacja Renaty Greenspan, w zbiorach autora.

${ }^{31}$ Artur Chwalibogowski (1899-1964) - lekarz pediatra; docent Uniwersytetu Jana Kazimierza we Lwowie; ordynator Oddziału Wewnętrznego dla Dzieci Państwowego Szpitala Powszechnego we Lwowie. W Szczecinie był organizatorem i pierwszym kierownikiem Kliniki Chorób Dziecięcych; profesor medycyny; od 1950 r. w Katowicach, twórca śląskiej szkoły pediatrii, pracował także na uczelniach medycznych Wrocławia i Zabrza; 70 lat..., s. 65. 
w sierpniu 1948 r. Warunkiem zgody na demobilizację był wyjazd na tzw. ziemie odzyskane. Gelber przystał na tę propozycję. Ministerstwo Zdrowia skierowało go na stanowisko lekarza, starszego asystenta w Klinice Pediatrycznej Akademii Lekarskiej w Szczecinie i jednocześnie ordynatora Oddziału Dziecięcego Zakaźnego w Szpitalu Miejskim nr 1 (przy ul. Arkońskiej), tutaj prowadził jednocześnie oddział szkarlatynowy, obserwacyjny i chorych na chorobę Heinego-Medina. Zainicjował powstanie w szpitalu Dziecięcej Izby Przyjęć i Pododdziału Obserwacji Dziecięcej. Ponadto był też przewodniczącym Zakładowego Komitetu Odbudowy Warszawy. W drugiej połowie lat pięćdziesiątych zaczął także udzielać się w Dzielnicowej Radzie Narodowej Szczecin-Pogodno, gdzie oceniano go jako „Wzór pracowitości”.

Doceniano jego działalność, przyznając odznaczenia zarówno wojskowe, jak i cywilne. W lipcu 1946 r. został wyróżniony Odznaką Grunwaldzką, trzy miesiące później Medalem Zwycięstwa i Wolności. W 1955 r. otrzymał medal 10-lecia Polski Ludowej, w 1958 r. odznakę Gryfa Pomorskiego, a w 1966 r. Odznakę Tysiąclecia $^{32}$. W 1952 r. Komitet Miejski PZPR pytał uczelnię o postawę społeczno-polityczną pracownika (Gelber przez całe życie pozostawał bezpartyjny). W opinii przesłanej przez akademię, poza podkreśleniem jego fachowości i inteligencji określono jego stosunek do „obecnej rzeczywistości” i ZSRR jako pozytywny ${ }^{33}$.

\section{Praca zawodowa}

Prawdopodobnie ze względu na braki kadrowe w nowo utworzonej uczelni Akademii Lekarskiej przez 12 dni był intendentem, następnie przez 1,5 miesiąca kierownikiem Wydziału Gospodarczego, a od października 1948 r. do lutego 1951 starszym asystentem w Klinice Pediatrycznej. Zwolnił się z uczelni na własną prośbę w związku z nawałem pracy na stanowisku ordynatora Oddziału Dziecięcego Zakaźnego w Wojewódzkim Szpitalu Zakaźnym Szczecinie (przy ul. Arkońskiej $)^{34}$. Pewną ciekawostką jest, że planowano, aby cały oddział Gelber prowadził z pomocą jedynie dwóch asystentów i 3-4 absolwentów. Funkcję tę Gelber sprawował do końca 1962 r. Odszedł ze szpitala na własną prośbę, argumentując dyskryminacją ze strony dyrekcji szpitala ${ }^{35}$. Konkretne powody podjęcia tej decyzji nie są dziś jasne.

\footnotetext{
${ }^{32}$ APUM, Akta personalne Jerzego Gelbera.

${ }^{33}$ Ibidem.

${ }^{34}$ Ibidem.

${ }^{35}$ Archiwum Państwowe w Szczecinie (dalej: APSz), Samodzielny Publiczny Wojewódzki Szpital Zespolony w Szczecinie (dalej: SPWSZ), sygn. 376, Akta osobowe Jerzego Gelbera. Bp. Gelber pisał: „Komunikowałem już kilkakrotnie, że na przestrzeni ostatnich miesięcy ponownie miały miejsce liczne akty dyskryminowania mnie przez dyrektora szpitala. Ponieważ Woj. Wydział Zdrowia, do którego zwracałem się z prośbą o pomoc, Niechciał lub nie mógł mi jej udzielić,
} 
W listopadzie 1950 r. został zatrudniony jako kierownik Poradni dla Matki i Dziecka Szpitala Wojewódzkiego Urzędu Bezpieczeństwa. Co ciekawe, w ankietach zarówno UB jak i uczelni, wypełnianych przez samego zatrudnianego, wyznanie Gelbera funkcjonuje jako rzymsko-katolickie. Nie taił jednak faktu, że ukrywał się w czasie wojny pod przybranym nazwiskiem oraz że posiadał bratową w Wielkiej Brytanii, dwie siostry przyrodnie i przyrodniego brata w Stanach Zjednoczonych. Urząd podejrzewał także, że Gelber współpracował z podziemiem w czasie gdy się ukrywał oraz pozyskał informację, że przed wojną sympatyzował z sanacją ${ }^{36}$. UB oceniał, że Gelberowie znani są jako osoby, „które lubią wspominać dobre czasy przedwojenne, gdzie dobrze im się powodziło”, zaś „sprawa klasy robotniczej i cele w Polsce demokratycznej" są im zupełnie obce ${ }^{37}$. W listopadzie 1951 r. Gelber odszedł z pracy w szpitalu WUBP.

W styczniu 1953 r. uzyskał specjalizację II stopnia z pediatrii, a w $1954 \mathrm{r}$. w zakresie chorób zakaźnych. W czerwcu 1959 r. obronił pracę doktorską. Rozpoczął także kierowanie poradnią przeciwgruźliczą Dyrekcji Okręgowej Kolei Państwowych. Przez pewien czas prowadził również praktykę prywatną i pełnił funkcję konsultanta wojewódzkiego ds. choroby Heinego-Medina.

W lutym 1955 r. Gelber został ponownie zatrudniony w Pomorskiej Akademii Medycznej [PAM] jako adiunkt w II Klinice Pediatrycznej na pół etatu, w listopadzie 1962 r. został przeniesiony do I Kliniki Pediatrycznej na pełny etat $^{38}$. W lutym 1964 jego przełożona, kierownik I Kliniki Pediatrycznej Julia Starkiewicz ${ }^{39}$ oceniała go jako bardzo zdolnego dydaktyka, ambitnego naukowca, który zaplanował rychłe oddanie pracy habilitacyjnej, posiadającego znaczący dorobek (w $1966 \mathrm{r}$. było to 20 prac), a ponadto cieszącego się uznaniem i autorytetem młodszych kolegów. Dwa lata później w dyskusji nad mianowaniem Gelbera na stanowisko docenta etatowego dziekan Wydziału Lekarskiego

a wytworzona ostatnio sytuacja uniemożliwia mi dalsze prawidłowe pełnienie moich tak odpowiedzialnych obowiązków, proszę o zwolnienie mnie z zajmowanego stanowiska $\mathrm{w}$ jak najszybszym terminie, nie później niż do dnia 31. XII b.r.” Dyrektor Marian Habela zgadzając się na zwolnienie Gelbera uznawał zarzut za niesłuszny i nieuzasadniony.

${ }^{36}$ AIPN Sz, sygn. 0019/1342, Akta personalne Jerzego Gelbera, Pismo z 16 XI 1950 r. do Naczelnika Wydziału Personalnego WUBP w Szczecinie, k. 34.

${ }^{37}$ Ibidem.

${ }^{38}$ PUM, Akta personalne Jerzego Gelbera.

39 Julia Starkiewicz (1908-1978) - lekarz pediatra, profesor PAM w Szczecinie; absolwentka Wydziału Lekarskiego Uniwersytetu Warszawskiego; przed II wojną światową pediatra w Warszawie i Lwowie; w czasie Powstania Warszawskiego lekarz w szpitalu przy ul. Mokotowskiej, po kapitulacji wysiedlona z Warszawy; 1947 dr n. med.; adiunkt na Uniwersytecie Warszawskim; od 1948 r. w Szczecinie; adiunkt w Klinice Pediatrycznej; od 1954 r. docent; od 1961 r. prof. nadz.; od 1971 r. prof. zw.; od 1957 kierownik I Kliniki Pediatrycznej; od 1968 r. kierownik Katedry Pediatrii; od 1970 dyrektor Instytutu Pediatrii; od 1975 r. na emeryturze; 1967-1968 prorektor PAM; promotor 19 prac doktorskich; autorka ok. 50 prac naukowych; członek PZPR od $1953 \mathrm{r}$. 70 lat..., s. 162. 
doc. Alfons Wojewski ${ }^{40}$ zaznaczał, że Gelber jest powszechnie znany, a jego nominacja będzie korzyścią dla całej akademii, podobnie prof. Eugeniusz Miętkiewskii ${ }^{41}$ : „doc. Gelber jest nam w Szczecinie potrzebny”, zaś jego bezpośrednia przełożona podkreśliła „wybitne zdolności dydaktyczne” lekarza. Senat uczelni przegłosował wówczas jego awans jednogłośnie ${ }^{42}$. Ponadto przewidywano, że Gelber będzie mógł objąć stanowisko kierownika kliniki Chorób Zakaźnych, którą planowano utworzyć, a Wydział Zdrowia WRN wyrażał nadzieję na jego fachowy nadzór nad przebudową i modernizacją szpitala zakaźnego ${ }^{43}$. Jego pozycja zawodowa była bardzo mocna, opinie przełożonych, władz uczelni wyłącznie pozytywne, równoległe do planów wykorzystania jego wiedzy i zdolności organizacyjnych w rozwoju służby zdrowia na Pomorzu Zachodnim.

Jednocześnie Gelber lubił pracę na uczelni, odnajdywał się zarówno w dydaktyce, jak i badaniach naukowych. Jego pierwszym artykułem był opublikowany w 1953 roku Przyczynek do zagadnienia tularemii u dzieci ${ }^{44}$. Gelber osobiście stykał się z tą ostrą chorobą zakaźną w swojej pracy ${ }^{45}$. W kolejnych swoich badaniach Gelber skupił się na błonicy ${ }^{46}$. Analizował również występowanie u dzieci

${ }^{40}$ Alfons Wojewski (1912-1992) - urolog i chirurg; absolwent Wydziału Lekarskiego Uniwersytetu w Poznaniu; uczestnik kampanii wrześniowej i konspiracji (szef służby zdrowia organizacji „Gryf Pomorski”; więzień Stutthofu; od 1945 r. asystent w Szpitalu Powiatowym w Wejherowie. 1946 r. doktor nauk medycznych; w 1949 r. aresztowany przez Urząd Bezpieczeństwa; 1946-1949 r. był dyrektor i ordynator oddziału chirurgicznego i ginekologicznego Szpitala Powiatowego w Kwidzyniu; 1950-1955 r. adiunkt na Oddziale Urologicznym Kliniki Chirurgicznej AM w Gdańsku i dyrektor Szpitala Klinicznego; od 1955 r. organizator i kierownik Kliniki Urologicznej PAM; od 1961 r. docent, nast. prof. zwycz.; organizator pierwszego w województwie ośrodka dializy pozaustrojowej; przez dwie kadencje dziekan Wydziału Lekarskiego i prorektor PAM; autor ponad 120 prac naukowych; w 1978 r. przeszedł na emeryturę i przeniósł się do Warszawy. 70 lat ..., s. 177.

${ }^{41}$ Eugeniusz Miętkiewski (1914-2002) - fizjolog, internista; absolwent Wydziału Lekarskiego Uniwersytetu Poznańskiego, następnie asystent i adiunkt na tej uczelni; jeniec Stalagu XXB; od 1940 r. lekarz w Słupcy; 1946-1949 lekarz w Szpitalu Kolejowym w Poznaniu; od 1950 r. w Szczecinie; profesor zwyczajny (1967), wykładowca Pomorskiej Akademii Medycznej; 1954-1955 prodziekan Wydziału Lekarskiego; 1955-1956 prorektor ds. nauczania; 1956-1959 prorektor ds. nauki; 1970-1983 dyrektor Instytutu Fizjologiczno-Chemicznego; 1985 doctor honoris causa PAM; 1962-2000 redaktor naczelny „Annales Academiae Medicae Stetinensis - Roczniki Pomorskiej Akademii Medycznej w Szczecinie”; autor i współredaktor ok. 260 prac naukowych. 70 lat..., s. 129.

${ }^{42}$ PUM, akta osobowe Jerzego Gelbera.

${ }^{43}$ Ibidem.

${ }^{44}$ J. Gelber, „Pediatria Polska” 1953, nr 8, s. 699-707.

45 Tularemia to ostra choroba zakaźna, wywoływana przez bakterię Francisella tularensis. Przenoszona jest przez komary lub kleszcze, zakażenie może nastąpić także poprzez styczność z zakażonymi płynami ustrojowymi oraz poprzez wdychanie zakażonego kurzu. Por. Choroby zakaźne i pasożytnicze, red. Z. Dziubek, Warszawa, 2003, s. 154-155.

${ }^{46}$ J. Gelber, H. Kuntsman, S. Świerczewski, Typy Maczugowców Błonicy występujące w województwie szczecińskim w latach 1952-1954, „Medycyna Doświadczalna i Mikrobiologia” 1955, nr 7 , s. 59-63; J. Gelber, Z. Kraszewska, Glikokortykoidy w leczeniu błoniczego uszkodzenia mięśnia sercowego, „Pediatria Polska” 1962, nr 37, s. 1-15. 
tzw. grypy azjatyckiej (H2N2), której pandemia mająca swoje źródło w Chinach w $1957 \mathrm{r}^{47}$ Inne pola badań Gelbera to choroba Heinego-Medina ${ }^{48}$, nagminne wirusowe zapalenie wątroby ${ }^{49}$, Choroba Bornholmska (pleurodynia, diabelska grypa ${ }^{50}$, świnka ${ }^{51}$, odmiedniczkowe zapalenie nerek ${ }^{52}$.

\section{Zbędny}

W 1961 r. ze względu na swoje kontakty zagraniczne Gelber wzbudził ponownie zainteresowanie SB. Były to wówczas działania typowe dla policji politycznej, niezwiązane z pochodzeniem czy religią rozpracowywanej osoby. Skupiano się na kontaktach zagranicznych, a takich kontaktów ordynator miał wiele, w tym przede wszystkim z rodziną brata Ludwika z Wielkiej Brytanii.

W 1964 r. podjęto nieskuteczną próbę pozyskania Gelbera do współpracy, ale po przeprowadzeniu kilku rozmów zrezygnowano, uznając że nie jest wobec SB szczery i że należy spodziewać się odmowy. Ponadto, jak notowano: „jego stosunek do kwestii mniejszości narodowej, którą reprezentuje odzwierciedla wsteczne poglądy i zapatrywania" ${ }^{53}$. Do roku 1967 nie dostrzegano w postawie Gelbera nic niewłaściwego. Potem zaś wszystko się zmieniło. Rozwinięto inwigilację. Nacisk, także dający się odczuć podsłuch telefoniczny, wizyty funkcjonariuszy aparatu bezpieczeństwa w miejscu pracy i na uczelni dzieci, stały się niemalże codziennością.

${ }^{47}$ J. Gelber, Powikłania grypy azjatyckiej u dzieci, „Pediatria Polska” 1959, nr 34, s. 849-857. Autor artykułu stwierdził, że u dzieci przebieg choroby był na ogół łagodny, ponieważ częstość zgłoszeń do szpitala w związku z zachorowaniem wynosiła ok. $27 \%$.

48 J. Gelber, A. Małolepszy, Wpływ ostrych chorób zakaźnych wieku dziecięcego na chorobę Heinego-Medina, „Przegląd Epidemiologiczny” 1959, nr 13, s. 339-346. Poliomyelitis, czyli choroba Heinego-Medina, to choroba zakaźna przenoszona drogą fekalno-oralną. Wzrost zachorowań wystąpił w drugiej połowie XIX w., a na początku XX w. przybrał rozmiar pandemii. Dzięki szczepionce wynalezionej przez polskiego lekarza Hilarego Koprowskiego w 1950 r. udało się ograniczyć masowe zachorowania, a tym samym liczbę zgonów z powodu polio.

${ }^{49}$ J. Gelber, E. Cieślak, Przemiana żelaza $w$ nagminnym zapaleniu wątroby u dzieci, „Roczniki Pomorskiej Akademii Medycznej” 1961, nr 7, s. 245-260; J. Gelber, A. Oszczak, Obraz immunoelektroforetyczny surowicy krwi w nagminnym zapaleniu wątroby u dzieci, „Pediatria Polska” 1962, nr 37, s. 1179-1190; J. Gelber, D. Kaczmarek, J. Maj, U. Nowotko, Zaburzenia krzepnięcia krwi w nagminnym zapaleniu wątroby u dzieci, „Przegląd Epidemiologiczny” 1962, nr 16, s. 159-166.

${ }^{50}$ J. Gelber, J. Golba, J. Maj, Epidemia choroby bornholmskiej u dzieci, „Pediatria Polska” 1962, nr 37, s. $1033-1040$.

${ }^{51}$ J. Gelber, J. Andrzejewski, A. Bogunowicz, Badania serologiczne w rozpoznawaniu nagminnego zapalenia przyusznic u dzieci, „Pediatria. Polska” 1966, nr 41 (2), s. 129-138.

52 J. Gelber, H. Śliwińska, E. Rydzewska, D. Pozorska, Zachowanie się niektórych mechanizmów odpornościowych u królików $w$ doświadczalnym odmiedniczkowym zapaleniu nerek. Część II Badania bakteriologiczno-immunologiczne, „Pediatria Polska” 1970, nr 45 (1), s. 21-31.

53 AIPN, sygn. 009/304, Kwestionariusz ewidencyjny krp. „Pediatra”, Raport z 11 XII 1965 r., k. 55. 
Ciekawe informacje przynosi notatka SB z 21 marca 1968 r., która miała powstać na podstawie rozmowy ze studentem PAM, traktowanym jako tzw. kontakt poufny. Specyfika tego dokumentu polega na tym, że ukazuje on stosunki na uczelni z innej perspektywy niż przed 1967 r., z perspektywy, którą obserwujemy wówczas powszechnie w dokumentach partyjnych, administracyjnych, SB. Według tego źródła w czasie zebrania Związku Młodzieży Socjalistycznej PUM pojawiły się wypowiedzi „prosyjonistyczne i antypolskie”, jednocześnie miejsca na praktykach zagranicznych otrzymali głównie studenci pochodzenia żydowskiego, a co więcej informator „wykry”” grupę profesorów pochodzenia żydowskiego, „którzy są uprzedzeni do studentów narodowości polskiej”, co miało skutkować m.in. niepowodzeniem na egzaminach niektórych adeptów medycyny. Do grupy tej zaliczył m.in. Jerzego Gelbera, ale także Marka Eisnera, Juliana Szenkelbacha ${ }^{54}$, małżeństwo Murczyńskich ${ }^{55}$. Co więcej rzekomy student przekazał również tak szczegółowe informacje, jak wydatki Gelbera na zorganizowanie przyjęcia dla rodziny z Anglii. Jak to zapisano: „studenci zastanawiają się skąd on to zdobył, że tak lekko puścił" 56 .

Dalej pisano: „reasumując kadra profesorska PAM narodowości żydowskiej tworzy zgraną klikę, która wszelkimi siłami stara się pomóc studentom narodowości żydowskiej, nieraz w nauce bardzo słabym. Student narodowości polskiej, który podpadnie u jednego Żyda jest następnie «wykańczany» przez innych Żydów, aż do usunięcia ze studiów włącznie. Studenci narodowości żydowskiej tworzą zgraną klikę w czasie ich rozmowy podchodzący do grupy polski student nawet mile przez Żydów widziany jako kolega powoduje natychmiastową zmianę tematu rozmowy u Żydów. Nie można od nich usłyszeć żadnego komentarza na temat wydarzeń dotychczas zaistniałych" 57 . Chodzi w tym przypadku o wydarzenia Marca 1968 r., w tym wrzenie w Szczecinie, które miało miejsce zwłaszcza w między 11 a 15 marca ${ }^{58}$. Już dwa tygodnie później SB dochodzi do wniosku, że Gelber w czasie konfliktu na Bliskim Wschodzie wykazywał „postawę proizraelską”, chociaż wcześniej nie

${ }^{54}$ Julian Szenkelbach (1924-2012) - lekarz ginekolog; w czasie wojny początkowo w Armii Czerwonej, w 1943 r. wstąpił do Dywizji Kościuszkowskiej, nast. w 3. Zapasowym Pułku Piechoty WP; po zdemobilizowaniu w Urzędzie Bezpieczeństwa Publicznego jako radiooperator; w $1948 \mathrm{r}$. służbowo przeniesiony do Krakowa; od 1951 r. pracownik szpitala WUBP; od 1954 r. w Szczecinie, dyrektor administracyjny Pomorskiej Akademii Medycznej, następnie zastępca dyrektora ds. socjalnych Huty Szczecin i dyrektor administracyjny Szczecińskich Zakładów Papierniczych; od 1955 r. zatrudniony jako lektor KW PZPR; od 1956 r. student PAM; nast. asystent w II Klinice Ginekologiczno-Położniczej PAM; w V 1968 r. zwolniony z pracy, nast. lekarz w Izraelu. AIPN Sz, sygn. 009/303, Sprawa operacyjna „Działacz”.

${ }^{55}$ AIPN Sz, sygn. 009/304, Notatka służbowa z 21.03.1968 r., k. 56-58.

${ }^{56}$ Ibidem.

${ }^{57}$ Ibidem.

${ }^{58}$ Szczeciński marzec '68. Inteligencki protest $w$ robotniczym mieście z Erykiem Krasuckim rozmawia Adam Zadworny, „Gazeta Wyborcza Szczecin” 9 III 2018, s. 5. 
posiadano na ten temat żadnych informacji ${ }^{59}$. To oczywiście jest prawdopodobne, bowiem powszechnie środowisko żydowskie, ale nie tylko ono, sympatyzowało z Izraelem, nie zaś wspieranymi przez ZSRR Arabami.

W maju 1968 r. SB założyła tzw. kwestionariusz ewidencyjny o kryptonimie „Pediatra”, podając jako powód inwigilacji „utrzymywanie kontaktów z kadrą kierowniczą PAM wywodzącą się spośród osób narodowości żydowskiej i reprezentującej wrogie Polsce - syjonistyczne poglądy" ${ }^{60}$. Znając skutki działań z dzisiejszej perspektywy można stwierdzić, że rzeczywistym celem działań policji politycznej było zmuszenie Gelbera do emigracji, mimo że także w tej instytucji oceniano, że sprawa dotyczy dobrego lekarza i naukowca, cieszącego się powszechnym uznaniem.

Zaczęto bliżej interesować się kontaktami Gelberów. Wśród częstych gości wymieniano Leona Szechtera wiceprzewodniczącego Prezydium Wojewódzkiej Rady Narodowej, lekarzy - Czesława Murczyńskiego, Edwarda Lichta ${ }^{61}$ (nie żył już od trzech lat), Szymona Remigolskiego ${ }^{62}$, Karola Stańskiego. Szczególnie zwracano uwagę na osoby pochodzenia żydowskiego.

Wzmocniono inwigilację, z której naturalnie sam kontrolowany zdawał sobie sprawę. Już po złożeniu dokumentów emigracyjnych Gelber w czasie jednego ze spotkań towarzyskich mówił, że wyjazd jest koniecznością, wynikającą z „mocnego dokuczania mu ze względu na narodowość" ${ }^{3}$. Któregoś popołudnia we wrześniu $1968 \mathrm{r}$. po powrocie z pracy oznajmił domownikom, że planowane jest jedno z kolejnych zebrań na uczelni, w czasie którego oczekiwane jest, że on potępi Izrael, czego nie zamierzał uczynić. Prawdopodobnie przełomowa dla decyzji o wyjeździe była rozmowa z rektorem Adamem Krechowieckim ${ }^{64}$,

${ }^{59}$ AIPN Sz, sygn. 009/304, Kwestionariusz ewidencyjny krp. „Pediatra”, Notatka informacyjna z 5.04.1968 r., k.59.

${ }^{60}$ Ibidem, Formularz, k. 5 .

${ }^{61}$ Edward Licht (1912-1965) - lekarz pediatra; absolwent medycyny Uniwersytetu w Parmie; w czasie wojny w Armii Czerwonej; lekarz szpitala w Ałma-Acie; po wojnie w Szczecnie; doc. PAM. M. Ptaszyńska, E. Licht (1912-1965) - szkic do portretu pediatry, „Polish Biographical Studies" 2018, s. 186-196.

${ }^{62}$ Szymon Remigolski (1912-2007) - lekarz chirurg; absolwent Wydziału Lekarskiego USB w Wilnie. W czasie okupacji wraz z rodzicami i bratem wileńskim getcie; po ucieczce ukrywał się na prowincji pod przybranym nazwiskiem Szymon Milewski; jako pracownik urzędu pracy w Ucinie sam oddelegował się do Austrii, gdzie znalazł zatrudnienie jako chirurg w szpitalu w Mauerbach koło Wiednia; aresztowany przez Gestapo, osadzony w obozie koncentracyjnym Dachau; po wyzwoleniu chirurg w Schwabing koło Monachium. W 1948 r. przyjechał do Szczecina, gdzie rozpoczął pracę w 109. Szpitalu Garnizonowym, wkrótce obejmując stanowisko ordynatora Oddziału Chirurgii; wyrzucony w czasie kampanii antysemickiej w 1967 r.; następnie lekarz w przychodni kolejowej i przychodni specjalistycznej. Zmarł w 2007 r. w Szczecinie.

${ }^{63}$ AIPN Sz, sygn. 009/304, Kwestionariusz ewidencyjny krp. „Pediatra” tw. Wernicki 9.12.68, Doniesienie, k. 68.

${ }^{64}$ Adam Krechowiecki (1913-1991) lekarz, specjalista anatomii, profesor medycyny; absolwent Wydziału Lekarskiego UJK we Lwowie; członek zespołu Rudolfa Weigla; pracownik Instytutu 
w której dowiedział się, że nie ma szans na uzyskanie samodzielnej katedry, oraz że planowana jest czystka, w wyniku której będzie musiał być zwolniony z pracy. Rektor powołał się przy tym na polecenie z Warszawy ${ }^{65}$. Gelber zrozumiał, że jedynymi powodami takiej decyzji są polityka i antysemityzm. Nie czuł jednak żalu do rektora, w opinii przekazanej w domu usprawiedliwiał przełożonego koniecznością wykonywania poleceń. Rozmowę z rektorem miała również córka Renata, która od kilku miesięcy pracowała już jako lekarz w szpitalu przy ul. Arkońskiej na oddziale wewnętrznym kierowanym przez prof. Eisnera, a której bronić postanowili koledzy. Krechowiecki reagował wówczas jak się wydawało sensowną argu-

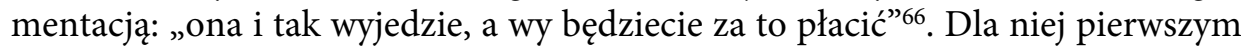
szokiem związanym $\mathrm{z}$ wybuchem antysemityzmu w Polsce była sytuacja w czasie letnich kolonii, na których pracowała, gdy przyjechała do szpitala $\mathrm{z}$ dzieckiem po wypadku, a lekarz dyżurny zwrócił się do niej słowami: „od Żydów pacjentów nie przyjmujemy" ${ }^{67}$. Po powrocie do Szczecina, gdy antysemicka kampania była już w swoim apogeum, Renata przekazała najbliższym, że wydaje się jej, że to jest początek końca. Jej brat Aleksander, urodzony w 1948 r., student trzeciego roku medycyny, zapamiętał zaś swoje myśli, gdy po marcowych zamieszkach jadąc tramwajem czytał „Kuriera Szczecińskiego”, a dominująca narracja gazety skupiała się wokół „niepolsko” brzmiących nazwisk aresztowanych studentów i „żydowskich inspiratorów" ${ }^{68}$. Oboje zrozumieli wówczas po raz pierwszy, że dla nich w Polsce miejsca może zabraknąć, mimo że kwestie polsko-żydowskie dotychczas dla nich zupełnie nie istniały. Jak wspomina po latach Aleksander: „nie lubiłem tego systemu, tylko nie wiedziałem, że z nami to wszystko rozegra się tak szybko i gwałtownie". Jednocześnie w swoim najbliższym otoczeniu przyjaciół i znajomych nie dostrzegali przejawów antysemityzmu, przychodziło to $\mathrm{z}$ zewnątrz i otaczało coraz mocniej ${ }^{69}$.

Ostatnią rozmowę z Gelberem odbyła jego przełożona, prof. Julia Starkiewicz, która prosiła go, aby sam zwolnił się z pracy. Zapytana o powód odpowiedziała, że z przyczyn politycznych. Gelber odpowiedział czarnym żartem: „chodzi o ustawy norymberskie?". Po jego wyjściu z gabinetu Starkiewicz płakała ${ }^{70}$. Wobec domowników Gelber senior oznajmił, że ma już dość presji i trzeba będzie wyjechać, przy czym pozostawił wolną rękę dzieciom. Zarówno one, jak i żona (która

Badań nad Tyfusem Plamistym i Wirusami; wykładowca w Lublinie; Gdańsku i od 1949 r. w Szczecinie; 1956-1971 dziekan Wydziału Lekarskiego PAM; 1962-1971 rektor PAM.

${ }^{65}$ Dotychczas Gelber pracował w katedrze kierowanej przez prof. Starkiewicz, z którą relacje popsuły się w tym okresie; AIPN Sz, sygn. 009/304, Notatka służbowa z 11.121968 r. ze spotkania z KP „Turysta” k. 72; Relacja Alexa Gelbera w zbiorach autora.

${ }^{66}$ Relacja Renaty Greenspan, w zbiorach autora.

${ }^{67}$ Ibidem.

${ }^{68}$ Relacja Alexa Gelbera, w zbiorach autora.

${ }^{69}$ Ibidem.

${ }^{70}$ Relacja Aleksandry Sikory w zbiorach autora. 
przypomniała, że nie zostawiła go w czasie okupacji, więc i teraz nie zamierza) zdecydowali się na wspólny wyjazd ${ }^{71}$.

Atmosfera w kraju, nacisk propagandowy, brak możliwości rozwoju, świadomość, że podobne problemy dotkną w Polsce jego dzieci były decydujące do podjęcia decyzji o emigracji. Przed 1968 r. takiej możliwości nie dopuszczano ze względu na zakorzenienie w Polsce, kulturze, życiu zawodowym, droga edukacyjna dzieci, grono przyjaciół i znajomych. Gelberowie byli bowiem rodziną zasymilowaną, co więcej żona Jerzego była praktykującą katoliczką. Bożonarodzeniowe śpiewanie kolęd rozpoczynało się od „Pierwszej Brygady” przy akompaniamencie babci Doroty. W ocenie SB dzieci nie informowano o żydowskim pochodzeniu ojca do 15. roku życia. Córka zaprzecza jednak tym informacjom (rodzice poinformowali ją o pochodzeniu, gdy miała 10 lat i sama odnalazła dokumenty w domu), przyznając jednocześnie, że nie kultywowano w domu żydowskich tradycji ${ }^{72}$. Także Jerzy Gelber czuł się Polakiem i uważał Polskę za swoją ojczyznę. Od czasu wojny poza swoją matką był ostatnią osobą z rodziny, która w Polsce zdecydowała się pozostać i z pewnością gdyby nie nagonka $1968 \mathrm{r}$. to tak by się stało.

W ocenie SB: „wśród sąsiadów tak on, jak i jego rodzina opinią cieszą się dobrą. Nadmieniam, że wymienieni są inteligentni, na dobrym poziomie ogólnym. Posiadają oni szerokie znajomości wśród lekarzy, z którymi wzajemnie się odwiedzają. Z sąsiadami żyją w zgodzie, jednak stosunków towarzyskich z nimi nie utrzymują. W stosunku do obecnego ustroju w miejscu zamieszkania wrogo nie wypowiadają się"73.

Służba Bezpieczeństwa podjęła próbę rozbicia rodziny. W początku grudnia Gelber rozmawiał z zastępcą naczelnika Wydziału Paszportów Kozakiem, próbując zrozumieć motywy, dla których tzw. dokument podróży otrzymał on sam, nie zaś żona i dzieci. Zasugerowano mu wówczas, że w rozumieniu religijnym żona i dzieci nie są Żydami. Odpowiedź była wówczas konkretna - albo wyjadą wszyscy, albo nikt ${ }^{74}$. Rozmawiano także z żoną sugerując, że wystarczyłaby jej deklaracja, że ojcem dzieci nie jest Gelber i trójka z nich mogłaby pozostać w Polsce.

Jeszcze chwilę przed wyjazdem - 16 grudnia bezpieka próbowała pozyskać do współpracy syna Aleksandra, a była to jedna z kolejnych rozmów, w których wcześniej namawiano go do pozostania w Polsce, przekonując o istnieniu spisku syjonistycznego w kraju. Jego współpraca miała być zresztą metodą na udowodnienie swojej polskości i patriotyzmu poprzez „niewielkie ofiary” w postaci „ostrzegania o grożącym niebezpieczeństwie”. Konkretnie chodziło o informowanie o ludziach działających „na szkodę kraju”. Oficer spotkał się wówczas

\footnotetext{
${ }^{71}$ Relacja Renaty Greenspan w zbiorach autora.

72 Ibidem.

${ }^{73}$ AIPN Sz, sygn. 009/304, Kwestionariusz ewidencyjny krp. „Pediatra”, k. 5.

${ }^{74}$ Ibidem, Notatka służbowa nr 312/68 z 10.12.1968, k. 71.
} 
z kategoryczną odmową i deklaracją, że życiową ambicją Gelbera jest jedynie bycie dobrym lekarzem. Funkcjonariusz zanotowal jedynie na zakończenie: „jestem przekonany że wobec ojca nie zachowa rozmowy w tajemnicy"75. Miał rację.

Gelberowie złożyli dokumenty emigracyjne 20 października 1968 r. Wcześniej jeszcze czekała ich wizyta celników i zatwierdzenie tego, co wolno im zabrać ze sobą. Jak się okazało jeden z celników był dawnym pacjentem powszechnie znanego pediatry Gelbera. Matka żegnała funkcjonariusza słowami „tylko nie rob żadnych świństw doktorowi"76.

Gelberowie opuścili Szczecin 28 grudnia 1968 r., żegnani na dworcu Szczecin Główny przez wielu przyjaciół. Pojechali do Warszawy. Dalej podróżowali szlakiem, który przemierzali też inni emigrujący z Polski w tym czasie Żydzi - do Wiednia. Ten odcinek pokonali samolotem. W Wiedniu okazało się, że Izrael nie jest zainteresowany emigrantami, którzy w rozumieniu prawa religijnego nie są stuprocentowymi Żydami. Zaoferowano im jednak pomoc w nawiązaniu kontaktu z Amerykanami i organizacją HIAS (Hebrew Immigrant Aid Society). Po dwóch tygodniach pociągiem wraz z innymi planującymi udać się do USA zostali przetransportowani do Rzymu. Dokładne kontrole (spowodowane m.in. brakiem wiary w to, że Gelber nie był członkiem partii) trwały cztery miesiące. 28 maja 1969 r. wylądowali w Nowym Jorku, zaczynając nowy etap życia. Jerzy miał wówczas 55 lat, był uchodźcą w obcym sobie kraju. Tutaj zdał wszystkie wymagane do utrzymania prawa zawodu egzaminy, podjął pracę w szpitalu w dzielnicy Queens, a w dzielnicy nazywaną Co-op City otworzył własną, ciesząca się powodzeniem praktykę pediatryczną, którą prowadził do emerytury. Otrzymał także etat adiunkta w Albert Einstein College of Medicine. Gdy zakończył karierę zawodową przeprowadził się do Kalifornii. Po kilkudziesięciu latach, w połowie lat osiemdziesiątych, będąc z wizytą u córki w Denver zapragnął pójść do synagogi, jednak pamięć tradycji zatarła się w nim na tyle, że przez dłuższy czas nie zorientował się, że bierze udział w modlitwie protestantów wynajmujących tę samą salę. Później chadzał do synagogi rzadko, w okolicy święta Rosz ha-Szana ${ }^{77}$.

Córka Gelbera Renata otrzymała pracę w Caledonian Hospital na Brooklynie, później rozpoczęła karierę jako lekarz wojskowy, zaś syn Aleksander pojechał na studia medyczne w Rzymie, na Sapienza Università di Roma"78.

Gelberowie przyjechali do Polski pierwszy raz w 1991 r. W czasie kilkumiesięcznego pobytu odwiedzili Warszawę i Szczecin. W Nowym Jorku z kolei odwiedził ich Marek Eisner, który w okresie antysemickiej nagonki zdecydował się pozostać w Szczecinie. Przekonywał wówczas, że podobnie jak on, Gelber powinien po prostu przeczekać, udawać, że nic się nie dzieje. Gelber odpowiadał jednak, że nie

\footnotetext{
${ }^{75}$ Ibidem.

${ }^{76}$ Relacja Renaty Greenspan w zbiorach autora.

77 Ibidem.

${ }^{78}$ Relacja Alexa Gelbera w zbiorach autora.
} 
umiał i nie chciał udawać, nie dostrzegać szykan, tolerować poniżenia, zwłaszcza, że zawsze, także na akademii, znalazł się ktoś kto nie dał mu zapomnieć, że jest inny, że jest Żydem. Przez całe życie emigracyjne zachował jednocześnie żal i sentyment. Także wnuk Jerzego Jonathan jest lekarzem. Zmarł 17 czerwca 1993 r.

W tym samym przedziale pociągu, w którym Gelberowie podróżowali z Wiednia do Rzymu w początku 1969 r., znalazła się inna lekarska rodzina wyrzucona wówczas ze Szczecina - rodzina Wajskol. Jej losy także czekają na opisanie.

\section{Anti-Semitic Campaign in the Milieu of Szczecin Doctors, 1967-68. The Case of Jerzy Gelber (Summary)}

The article is an attempt to fill in the gap in our current knowledge about the course of an antiSemitic purge conducted in the community of doctors since 1967. The narrative axis is the figure of the outstanding paediatrician Jerzy Gelber, one of the post-March emigrants. In contrast, the narrative context is the whole mechanism of the anti-Semitic campaign, the elements of which were not only propaganda in the media but also activities of the central, provincial, and basic party organisations of the health service. Another component of this mechanism is, naturally, the political police whose activities ranged from surveillance through the pressure on dismissal to decisions to issue the so-called travel document - they also require a thorough analysis. Thus, the author's purpose is to present in detail the life of the outstanding doctor, the victim of the purge conducted in Poland in 1967-68, but also an attempt to reveal the influence of the so-called great history on the life of an individual. The text is also a proposal to develop further research on the phenomenon of postMarch emigration using the biographical method, and to use it in a broader scope - not ending with the exodus, but also presenting the fate of Polish Jews after they left Poland.

\section{Bibliografia}

\section{Archiwa}

Archiwum Państwowe w Szczecinie

Archiwum Pomorskiego Uniwersytetu Medycznego

Archiwum Instytutu Pamięci Narodowej

Archiwum Wojskowego Biura Historycznego (CAW)

\section{Relacje}

Renaty Greenspan

Aleksandra Gelbera

Aleksandry Sikory

\section{Opracowania}

Choroby zakaźne i pasożytnicze, red. Z. Dziubek, Warszawa, 2003

Eisler J., Polska rok 1968, Warszawa 2006

Gelber J., Andrzejewski J., Bogunowicz A., Badania serologiczne w rozpoznawaniu nagminnego zapalenia przyusznic u dzieci, „Pediatria. Polska” 1966, nr 41 (2), s. 129-138

Gelber J., Cieślak E., Przemiana żelaza w nagminnym zapaleniu wątroby u dzieci, „Roczniki Pomorskiej Akademii Medycznej" 1961, nr 7, s. 245-260 
Gelber J., Golba J., Maj J., Epidemia choroby bornholmskiej u dzieci, „Pediatria Polska” 1962, nr 37, s. $1033-1040$

Gelber J., Kaczmarek D., Maj J., Nowotko U., Zaburzenia krzepnięcia krwi w nagminnym zapaleniu wątroby u dzieci, „Przegląd Epidemiologiczny” 1962, nr 16, s. 159-166

Gelber J., Kraszewska Z., Glikokortykoidy w leczeniu błoniczego uszkodzenia mięśnia sercowego, „Pediatria Polska” 1962, nr 37, s. 59-63

Gelber J., Kuntsman H., Świerczewski S., Typy Maczugowców Błonicy występujące w województwie szczecińskimw latach 1952-1954, „Medycyna Doświadczalna i Mikrobiologia” 1955, nr 7, s. $59-63$

Gelber J., Oszczak A., Obraz immunoelektroforetyczny surowicy krwi w nagminnym zapaleniu watroby u dzieci, „Pediatria Polska” 1962, nr 37, s. 1179-1190

Gelber J., Powikłania grypy azjatyckiej u dzieci, „Pediatria Polska” 1959, nr 34, s. 849-857

Gelber J., Śliwińska H., Rydzewska E., Pozorska D., Zachowanie się niektórych mechanizmów odpornościowych u królików w doświadczalnym odmiedniczkowym zapaleniu nerek. Część II - Badania bakteriologiczno-immunologiczne, „Pediatria Polska” 1970, nr 45 (1), s. 21-31

Gelber J., Małolepszy A., Wplyw ostrych chorób zakaźnych wieku dziecięcego na chorobę Heinego-Medina, „Przegląd Epidemiologiczny” 1959, nr 13, s. 339-346

Głowiński M., Marcowe gadanie: komentarze do słów 1966-1971, Warszawa 1991

Hanich A., Dekanaty i parafie administracji apostolskiej Śląska Opolskiego w latach 1945-1946, Opole 2009

Krasucki E., Historia kręci drejdlem. Z dziejów (nie tylko) szczecińskich Żydów, Łódź 2018

Marek Eisner, red. I. Kojder, Szczecin 2014

Mieczkowski J., Między emigracja a asymilacją. Szkice o szczecińskich Żydach w latach 1945-1997, Szczecin 1998

Oblicza marca, red. K. Rokicki, S. Stępień, Warszawa 2004

Osęka P., Marzec '68, Kraków 2008

Osęka P., Syjoniści, inspiratorzy, wichrzyciele. Obraz wroga w propagandzie Marca 1968, Warszawa 1999

Ptaszyńska M., E. Licht (1912-1965) - szkic do portretu pediatry, „Polish Biographical Studies” 2018, s. $186-196$

Rutkiewicz A., Działania desantowe służby zdrowia 1 Samodzielnej Brygady Spadochronowej w operacji „Market Garden”, „Przegląd Historyczno-Wojskowy” 2017, nr 2, s. 119-147

Stola D., Kampania antysyjonistyczna w Polsce 1967-1968, Warszawa 2000

Tożsamość po pogromie. Świadectwa i interpretacje Marca '68, red. A. Molisak, P. Czapliński, Warszawa 2019

70 lat Pomorskiego Uniwersytetu Medycznego w Szczecinie, red. I. Kojder, Szczecin 2018

\section{Prasa}

„Głos Szczeciński” 1967-1968

Ptaszyński R., Od Żydów pacjentów nie przyjmujemy, „Gazeta Wyborcza Szczecin” 15 III 2019, s. 4

Szczeciński marzec '68. Inteligencki protest $w$ robotniczym mieście z Erykiem Krasuckim rozmawia Adam Zadworny, „Gazeta Wyborcza Szczecin” 9 III 2018, s. 5 
Radosław Ptaszyński, dr hab. prof. Uniwersytetu Szczecińskiego; politolog, socjolog, historyk; pracownik Ośrodka Badań Biograficznych US, sekretarz redakcji Polish Biographical Studies; publikował m.in. na łamach „Tygodnika Powszechnego”, „Znaku”, „Polityki”; stypendysta Ośrodka Pamięć i Przyszłość we Wrocławiu; członek Polskiego Towarzystwa Historycznego, Polskiego Towarzystwa Studiów Żydowskich; nominowany do Nagrody Historycznej im. Kazimierza Moczarskiego (2019), Nagrody Książka Historyczna Roku im. Oskara Haleckiego $(2018,2019)$, Nagrody im. Jana Długosza (2019). Laureat Zachodniopomorskiego Nobla; opublikował m.in.: Stommizm. Biografia polityczna Stanisława Stommy, wyd. Znak, Kraków 2018.

Kontakt: radoslaw.ptaszynski@gmail.com 